\title{
Kampene, som styrer journalister og nyhedsmedier \\ - frispark og frispilninger i Bourdieus feltteoretiske arbejde
}

\author{
AF FLEMMING SVITH
}

\begin{abstract}
Denne artikel fremhæver feltteoriens oversete potentiale som analyseredskab på mesoniveau for medie- og journalistikforskning. Bourdieu anvender feltteorien til på makroniveau at betegne nyhedsproduktionen i vestlige lande som domineret af kommercielle interesser, og på mikroniveau er feltteorien anvendt $\mathrm{i}$ antropologiske redaktionsstudier af journalisters positioneringer. Denne artikel fremhæver feltteoriens styrke på mesoniveau til at begrebsliggøre strukturer, der eksisterer i historisk afgrænsede perioder. Der hersker specifikke konkurrencedynamikker mellem polariserede nyhedsmedier og mellem polariserede journalister, som disponerer nyhedsmedier og journalister til at handle på bestemte måder. Jeg undersøger feltteoriens følsomhed over for historisk afgrænsede konkurrenceforhold i en dansk case gennem konstruktion af fire felter, der demonstrerer forskellige konkurrencelogikker mellem henholdsvis aviser og journalister.
\end{abstract}

\section{Introduktion}

Det er 20 år siden, at Bourdieu gik til kamp mod, hvad han anså for journalisters og især tv-mediets tiltagende og urimelige 
magt i det franske samfund (Bourdieu, 1998/1996; 2005/1995; 1996/1992: 281). I sine analyser af aviser, tv og journalistik begik han imidlertid en række "frispark" med generaliseringer og simplificeringer, som bryder med hans egne teorier om, at det moderne differentierede samfund består af række mikrosamfund med hver sine spilleregler. Det ændrer dog ikke på, at hans feltteori om det moderne samfund tillige indeholder en række "frispilninger" til at forstå medier og journalistik i en bredere social og samfundsmæssig kontekst.

Formålet med denne artikel er at bidrage til at nyttiggøre feltteorien som redskab på mesoniveau i analysen af nyhedsproduktion ved på en operationel måde at inddrage sociale strukturer i medie- og journalistikforskning. Artiklen bygger på en Bourdieulæsning, som fremhæver den analytiske og åbne karakter af hans begreber. Det er ikke artiklens formål empirisk at undersøge konkrete styrkeforhold i eller mellem felter. I stedet er fokus på at identificere grupperinger og den specifikke logik i dens indbyrdes konkurrence om det at være journalist eller nyhedsmedie. Felter konstrueres med to poler i et logisk og objektivt modsætningsforhold. Artiklen anvender en dansk case til at konstruere fire felter, som demonstrerer vigtigheden af at afgrænse de strukturelle forhold i nyhedsmedier og journalistik i tid og rum, hvorved de adskiller sig fra Bourdieus mere makrosociologiske betragtninger om nyhedsmedier og journalistik.

Få kan være i tvivl om, at markedet for nyheder har ændret sig de seneste årtier som følge af blandt andet nye digitale medier. Sideløbende hermed har jobmarkedet i Danmark ændret sig for journalister, så mange i løbet af de seneste årtier er blevet ansat i virksomheder og private og offentlige organisationer med intern og ekstern kommunikation, strategisk information og PR. Disse strukturelle forandringer i mediers og journalisters mikroverdener kan feltteorien begribe, og den fremhæves i litteraturen som en anvendelig og frugtbar (Couldry, 2004: 170) og dominerende retning i medieforskningen (Anderson, 2008; Hovden, 2012; Zelizer, 2004). Imidlertid skelner den feltteoretiske tradition ikke tilstrækkeligt mellem medier og journalistik som to distinkte analyseobjekter med hver sine egenskaber (eksempelvis Benson \& Neveu, 2005; Bourdieu, 2005/1995; 1998/1996; Couldry, 2004, 2014; Marliére, 1998). Det er paradoksalt, eftersom netop styrken 
ved feltteorien er dens evne til at begribe specifikke differentieringslogikker og kausale mekanismer i det moderne samfunds mikroverdener (Couldry, 2004: 174).

Mine argumenter i denne artikel er for det første, at der er forskellige differentieringsmekanismer eller konkurrencelogikker i nyhedsmedier og i journalistik, hvorfor de - uanset tætte relationer - må forstås hver for sig.

For det andet, at felter i nyhedsmedier og journalistik bør konstrueres ud fra kontingente og specifikke strukturelle forhold frem for generelle makroforhold. Nedenfor konstruerer jeg fire felter, som afviger fra Bourdieus antagelse, at alle kulturelle produktionsfelter, ikke mindst produktionen af nyheder, er spændt ud mellem en kulturel og en økonomisk pol. I stedet peger jeg på kulturelle og politiske modsætningsforhold. Felterne konstrueres ud fra statistiske data (jf. Bourdieu \& Wacquant, 1992: 243; Bourdieu, 1998/1996: 41; Myles 2010: 145), aktørers positioneringer og den nationale og internationale litteratur om nyhedsmedier og journalistik. Med feltskitserne undersøger jeg teoriens følsomhed over for strukturer, der varierer mellem nyhedsmedier og journalistik og er tidsmæssigt afgrænsede.

Artiklen fortsætter ved at fremhæve positive og negative elementer i Bourdieus feltteoretiske arbejde i forhold til analyse af specifikke strukturelle forhold. Derpå følger mine skitser til to nyhedsmediefelter og to journalistfelter før og efter år 2000. ${ }^{1}$ Felterne konstrueres med to poler med hver sit rationale, objektive interesse og principper og med den specifikke konkurrencelogik, som polerne skaber. Afslutningsvis peger jeg på tre områder, hvor feltskitserne kan bidrage til feltteorien som analytisk redskab i medie- og journalistikforskning.

\section{De informerende "frispilninger" i Bourdieus feltteori}

I Bourdieus sociologiske teori om de moderne differentierede samfund er feltbegrebet helt centralt. Den sociale verden er opdelt i mere eller mindre relativt autonome mikroverdener med egne regler og mønstre i de deltagende aktørers adfærd. Disse mikroverdener begriber Bourdieu som felter, som han tillægger specifikke effekter på kulturel produktion, herunder journalistik. 
Imidlertid giver hans feltteoretiske arbejde mig grund til at fremhæve tre "frispilninger" og to "frispark" i studiet af medier og journalistik. Min påstand er, at Bourdieus feltteoretiske arbejde både fremmer og hæmmer forståelsen af medier og journalistik.

Feltteoriens første frispilning er, at den forankrer teori om medier og journalistik i en større social og samfundsmæssig kontekst. Felter definerer Bourdieu som et netværk af positioner mellem to modsatrettede poler organiseret efter en specifik logik (Bourdieu, 1993), som ikke er åbenlys, fordi felters regulariteter ikke er eksplicitte og kodificerede (Bourdieu \& Wacquant, 1992: 98). Polerne repræsenterer forskellige former for kapital eller magt, dvs. forskellige kvalifikationer, egenskaber, evner, kunnen og anerkendelse. Relationen mellem disse poler er konkurrence frem for samarbejde, solidaritet eller kærlighed. "We can indeed, with caution, compare a field to a game (jeu) although, unlike the latter a field is not the product of a deliberate act of creation, and it follows rules or better regularities, that are not explicit and codified. Thus we have stakes (enjeux) which are for most part the product of the competition between players." (Bourdieu \&Wacquant, 1992: 98).

Konkurrence forstås som et generelt regulerende princip i aktørers stræben efter forskellige typer af værdi som uddannelse, anerkendelse, opmærksomhed, penge og, som jeg nedenfor foreslår, mere specifikke værdier som fx praktisk professionalitet i journalistik (jf. Svith, 2014). Felter tilskrives relativ autonomi, hvilket er grundlaget for overhovedet at tale om en "egen" verden med poler og konkurrence. ${ }^{2}$ Det er værd at bemærke, at et felt er et analyseobjekt, som forskeren konstruerer med henblik på at forklare mønstre i aktørernes praksis (Bourdieu, 2005/1995: 30). Et felts forklaringskraft afhænger af, hvor meget aktørerne styres af feltets specifikke konkurrence. "In so far as the properties chosen to construct this space are active properties, the space can also be described as a field of forces: in other words, as a set of objective power relations imposed on all those who enter this field" (Bourdieu, 1991/1984: 230).

Feltteorien bygger på kausal sandsynlighedslogik (Christoforou \& Lainé, 2014: 6), hvilket betyder, at felter skaber mønstre eller regulariteter i journalisters og nyhedsmediers praksis. "Every subfield has its own logic, rules and regularities" (Bour- 
dieu \& Wacquant, 1992: 104). Praksis er bestemt af strukturelt baserede konkurrencerelationer mellem modstående grupper. "[B]y constructing the objective structure of the distribution of the properties attached to individuals or institutions, one acquires an instrument for forecasting the probable behaviors of agents occupying different positions within that distribution." (Bourdieu, 2004/2001: 58). Den kausale mekanisme, hvorigennem disse strukturelle forhold virker, er ifølge Bourdieu habitus, ${ }^{3}$ der " er et blandt flere principper for de agerendes produktion af praksisformer, omend det utvivlsomt er mere på spil end noget andet princip" (Bourdieu, 2005/1988: 103).

Feltteoriens rationale er, at konkurrenceforhold i afgrænsede territorier eller netværk regulerer aktørers praksis, uden at disse nødvendigvis er sig dette bevidst. Dermed bidrager feltteorien med sit fokus på kausale relationer i de sociale strukturer til at forstå medier og journalistik som en del af en social kontekst, hvilket er tiltrængt i medieteori (Hesmondhalgh \& Toynbee, 2008: 11). Feltteoriens første "frispilning" er derfor, at den kan anvendes til at identificere strukturer med modstillede grupperinger i en mikroverden, som disponerer aktører til en bestemt praksis.

Den anden frispilning er feltteoriens integration af forskellige analyseobjekter, eftersom en mikroverden kan bestå af individer eller organisationer (jf. Bourdieu \& Wacquant, 1992: 99); Bourdieu, 2004/2001: 64-65). Feltteorien giver dermed mulighed for at analysere nyhedsmedier og journalister i hver deres sociale rum.

Det tredje træk ved feltteorien er begrebernes åbenhed (Bourdieu \& Wacquant, 1992: 95), hvilket vil sige deres følsomhed over for variation i både tid og rum (Bourdieu, 2004/2001: 64). Kulturelle produktionsfelter har en række fælles strukturelle karakteristika som blandt andet oppositionelle grupper, konkurrencelogikker, fraktioner af dominerede og dominerende, hvilket Bourdieu refererer til som funktionelle homologier, dvs. fælles strukturelle træk. "But every one of these characteristics takes a specific irreducible form in each field (a homology may be defined as a resemblance within a difference)" (Bourdieu \& Wacquant, 1992: 105-106, 97). Opgaven er derfor at identificere specifikke egenskaber, der i en afgrænset periode karakteriserer en 
mikroverden som journalistik med henblik på konstruktionen af et felt.

\section{De problematiske "frispark" i Bourdieus feltteoretiske arbejde}

To træk ved Bourdieus feltteoretiske arbejde hæmmer teoriens mulighed for at identificere afgrænsede strukturer i nyhedsmedier og journalistik. Bourdieus første "frispark" er en grundlæggende og generel antagelse, som han knytter til moderne vestlige lande. Al kulturel masseproduktion i disse lande står splittet mellem at tjene penge eller skabe kultur. Kulturel masseproduktion er domineret af en ensartet konkurrencelogik ved at være spændt ud mellem en kommerciel pol og en kulturel pol (Bourdieu: 1998/1994: 6). Som Bourdieu anfører: "In other words, sales values, against which all specific autonomies have been constructed - all microcosms are constructed against the commercial, they all have this in common, including the legal field - become, if not dominant, then at least threatening, in every field." (Bourdieu, 2005/1995: 43). Det er ikke mindst tilfældet med nyhedsmedier "at the heart of print media or television, each one of which functions like a subfield, the opposition between a "cultural" pole and a "market" pole organizes the entire field. The result is a series of structures within structures" (Bourdieu, 1998/1996: 91).

Hvis vi accepterer Bourdieus antagelse, så er denne grundlæggende modsætning mindre interessant som forklaring af kulturel masseproduktion. Mens den kulturelle kapital varierer i underfelter som fx sproglige, akademiske eller intellektuelle egenskaber, fremstår anskaffelsen af penge i den kommercielle pol som en permanent baggrundsbetingelse, som kan være mere eller mindre dominerende (jf. Hallin \& Mancini, 2004: 288-291). I en diskussion af kausalitet i samfundsvidenskabelige forklaringer søger Gerring (2005) på linje med Bourdieu efter kausale forklaringer, der er skjulte, ikke åbenbare eller selvindlysende og det deraf afledte fokus på strukturelle variable. Imidlertid advarer Gerring mod at anvende mere eller mindre konstante baggrundsforhold som $\mathrm{fx}$ individers egeninteresse til at forklare adfærd: "Proper explanations seek out the most contingent cause from a 
field of possible factors. Thus the so-called cause is distinguished from background conditions - those factors which constitute the 'normal course of events.' (Gerring, 2005: 177). Den kommercielle egeninteresse er sådan et baggrundsforhold i al kulturel masseproduktion, der ikke er finansieret af stat eller organisationer. Økonomisk indtjening er derfor mindre interessant som forklaringsfaktor, hvorfor der i analysen af kulturel (masse)produktion er grund til at lede efter andre specifikke og unikke modsætningsforhold i de kulturelle produktionsfelter som fx journalistik eller nyhedsmedier. Det unikke ved mikroverdener er disse kontingente kausale forhold.

Bourdieus andet frispark er, at indtjening og kommercialisme tillægges en dominerende indflydelse på kulturel masseproduktion og i særdeleshed på journalistik og medier (Bourdieu, 2005/1995: 44; 1998/1996: 20, 70). Mens kulturel småproduktion (avantgardekunst) defineres som et underfelt med to poler, beskrives kulturel masseproduktion (fx journalistik) uden en egen konkurrencelogik (Bourdieu, 1996/1992: 124). "Everybody knows the "law" that if a newspaper or other news vehicle wants to reach a broad public, it has to dispense with sharp edges and anything that might divide or exclude readers" (Bourdieu, 1998/1996: 44). Hvilket harmonerer dårligt med, at Bourdieu forklarer kulturel masseproduktion på to franske aktualitetsmagasiner som en homologi mellem feltet og læserskarer i det omgivende sociale rum (Bourdieu, 2005/1995: 44-45). Det harmonerer bedre med, at "[j]ournalism is a microcosm with its own laws ...To say that it is independent or autonomous, that it has its own laws, is to say that what happens in it cannot be understood by looking only at external factors." (Bourdieu, 1998/1996: 39).

Delkonklusionen på de to ovenstående afsnit om Bourdieus feltteoriske arbejde er, at feltteorien egner sig til at kortlægge specifikke kulturelle, politiske eller professionelle strukturelt baserede relationer i henholdsvis nyhedsmedier og journalistik, der disponerer organisationers og individers praksis på bestemte steder og tidspunkter. Konkurrencen eller kampen handler om, hvad der skal anerkendes som bedste praksis blandt kombattanterne i feltet og dermed konverteres til symbolsk magt i kampen om den sociale og symbolske orden. De fire feltskitser nedenfor bygger på et udsnit af de danske nyhedsmedier og journalister, 
hvilket betyder, at det ikke er de eneste felter, der kan konstrueres.

\section{Pressens nyhedsmediefelt (1970'erne-1990'erne)}

Forandringen i danske nyhedsmedier i løbet af de seneste årtier giver grundlag for at konstruere to nyhedsmediefelter. Det første felt bygger alene de landsdækkende aviser, mens det andet felt inkluderer et bredere spektrum af nyhedsmedier. Med kommercialisering og opløsning af partipressen i Danmark halveredes antallet af selvstændige dagblade fra 1950'erne til 1970'erne (Søllinge, 1999: 85). Det skabte grundlaget for det første felt: Pressens nyhedsmediefelt. Det strækker sig fra 1970'erne til slutningen af 1990'erne (jf. figur 1). Feltet bygger på, at aviserne havde øget deres autonomi i forhold til de politiske partier og udviklet en egen logik (jf. Walgrave \& van Aelst, 2006: 98).

I pressens nyhedsmediefelt kæmper landsdækkende betalingsaviser om publikums interesse med oplag som målbart parameter, hvortil der knyttes status, prestige og annonceindtægter (Søllinge, 1999: 85). Udviklingen i de otte største avisers oplag kan ses i nedenstående grafik, hvor Berlingske Tidende, Morgenavisen Jyllands-Posten, Politiken, Børsen, Dagbladet Information og Kristeligt Dagblad er kategoriseret som publicistmedier, og B.T. og Ekstra Bladet er kategoriseret som tabloidaviser. ${ }^{4}$.



Figur 1. Danske landsdækkende betalingsavisers oplag og pressens nyhedsmediefelt 
Oplagsudviklingen i figur 1 viser, at tabloidaviserne først i 1970'erne opnår tilstrækkelig styrke til at udfordre publicistavisernes måde at være nyhedsavis på. Aviserne kæmper om forskellige kulturpræsentationers symbolske værdi.

Den publicistiske pol bygger på et rationale om systemafspejling baseret på en borgerlig kultur. Den publicistiske mediekapital er informationer på et generelt og abstrakt systemniveau med synliggørelse af magtfulde kilder og deres modstridende synspunkter og politiske dagsordener (jf. Bennett, 1990). Nyheder frames tematisk (jf. Iyengar, 1991) med væsentlige samfundsforhold som politik og økonomi, hvorved den publicistiske mediekapital kort kan karakteriseres som borgerligt-væsentlig.

Den tabloide pol bygger på et rationale om afspejling af "massernes" fornuft baseret på en folkelig kultur med en (populistisk) os/dem-dikotomi og moralsk indignation over absurditeter, magtmisbrug og ressourcespil (jf. Hjarvard, 1999). Nyheder frames episodisk (jf. Iyengar, 1991) med kriminalitet, socialstof, kendte personer og et person- og caseperspektiv (jf. Albæk, 2004: 53). Den tabloide mediekapital er informationer på den almindelige borgers horisont, som kort kan betegnes folkeligt-fængende.

Pressen nyhedsmediefelt er kulturel masseproduktion, der bygger på en kulturel distinktion mellem borgerligt-væsentligt og folkeligt-fængende, hvilket er en homologi til borgerskabets kultur og arbejderklassens kultur (jf. Hesmondhalgh, 2006: 215). De folkeligt-fængende nyhedsmedier er måske lidt misvisende karakteriseret som en amerikanisering, 'dumping' eller 'infotainment' (fx McNair, 1999: 2). Feltet ser ud til også at kunne inkludere tv-stationerne, fordi DR positionerede sig tæt på den publicistiske pol, mens TV 2 med start i 1989 positionerede sig tættere på den tabloide pol (jf. Hjarvard, 1999).

Konstruktionen af nyhedsmediefeltet med to kulturelle poler peger på, at kommercielle nyhedsmedier kan repræsentere klassekulturer på samme måde som de tidligere partibetalte aviser. Oplagstallene i figur 1 viser tillige, at den tabloide pol mister styrke efter år 2000, hvilket sandsynligvis svækker spændingen mellem publicistaviser og tabloidaviser, uden at den forsvinder helt. Til gengæld opstår der omkring år 2000 andre og stærkere spændinger i nyhedsmedierne. 


\section{Det distribuerede nyhedsmediefelt (2000'erne)}

I 1990'erne betyder udbredelsen af computere og internet, at de klassiske nyhedsmedier baseret på brugerbetaling udfordres af de såkaldte nye medier, som i løbet af ganske få år bryder de klassiske nyhedsmediers (avis, tv og radio) monopol på adgangen til offentligheden. "Internettet satte [...] fra sidst i halvfemserne helt nye betingelser for medieudviklingen ... Angrebene kom fra alle sider og fra mange typer modspillere: internetforetagender, gratisaviser, nye tv-kanaler" (Minke, 2008: 301). Den afgørende distinktion er ikke mellem avishuse og internetforetagender, men mellem betalte nyhedsmedier og gratis nyhedsmedier. Det skaber nye distinktioner internt på nyhedsmedier i både de borgerligt-væsentlige og folkeligt-fængende nyhedsmedier. ”The shift to an 'online first' policy on news reporting, moreover, means that a newspaper's website might cannibalise and publish the paper's major news story of the day as much as three to four hours ahead of the print edition's evening publication, leaving the newspaper without a strong front-page story." (Franklin, 2008: 635). Dermed opstår i 2000'erne konturerne af, hvad jeg betegner som det distribuerede nyhedsmediefelt, der er baseret på kampe mellem nyhedsmedier, som brugerne enten betaler for, eller som de kan få gratis. De gratis nyhedsmedier består fra sidst i 1990'erne af gratis onlineaviser, sociale medier, trykte landsdækkende gratisaviser og TV2, der fra 2004 blev frataget licensmidler og alene skulle finansieres af reklamer.

Strukturen i nyhedsmedierne i 2000'erne kan illustreres af to typer data: Avisers oplagsdata og surveydata af danskernes anvendelse af medietyper. Efter Jyllands-Posten startede den første danske gratis internetavis i 1996, viser surveydata, at i 2008 anvendte tre fjerdedele af danskerne (78 procent) gratis danske internetnyhedssider (Schrøder, 2010: 20), hvilket illustreres af den stiplede linje i figur 2. Oplagsdata viser, at gratisaviser distribueret som trafik- eller knudepunktsaviser i samme periode, tiltog i styrke. De trykte landsdækkende gratisaviser er Erhvervsbladet (før 1990-2006), Urban (2001-2011), MetroXpress (2001-), Nyhedsavisen (2006-2008) og 24timer (2006-2012). 


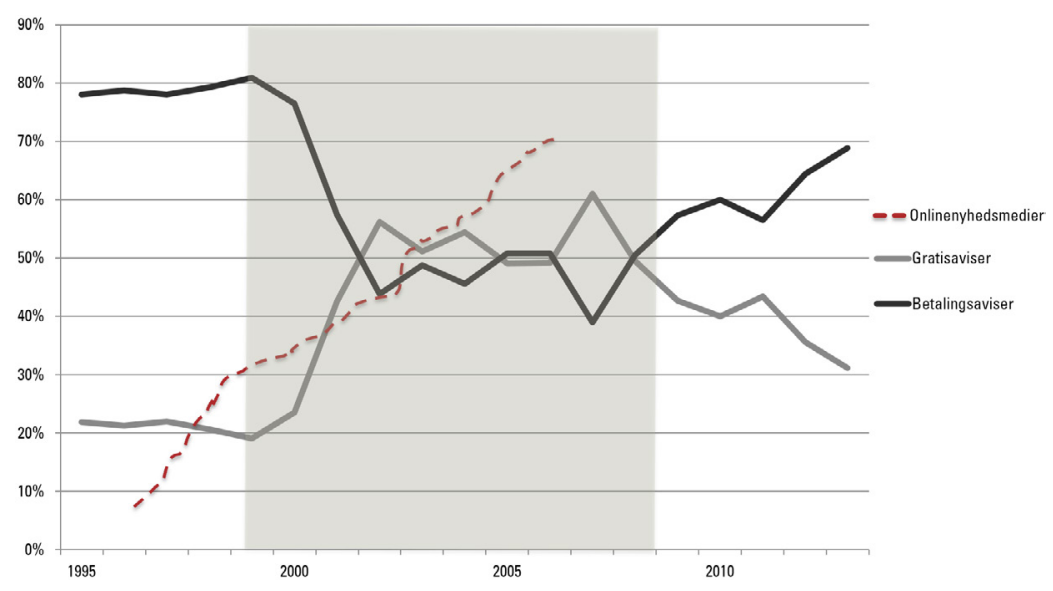

Figur 2. Danske landsdækkende avisers oplag, internetnyhedsmedier og det distribuerede nyhedsmediefelt ${ }^{5}$

Figur 2 viser, at de fire ovenfor nævnte trykte gratisaviser sammen med gratis onlinenyhedsmedier i løbet af ganske få år kom til at udgøre en alvorlig konkurrent til de otte landsdækkende betalingsaviser (både tabloid og publicist). Det distribuerede nyhedsmediefelt konstrueres med en aktørpol og en fontænepol. Aktørpolens mediekapital er nyhedsproduktion, hvilket bygger på en relativt arbejdsintensiv rationalitet med redaktionel idéudvikling, vinkling, supplerende oplysninger eller kildebrug (Holm m.fl., 2008: 228; Willig \& Lund, 2009: 164). Brugerbetalte nyhedsmedier positionerer sig som "langsomme" medier med forklaringer, baggrund og perspektiver. ${ }^{6}$ Deres mediekompetence er dagsordenfastsættelse gennem eksklusive nyheder.

Fontænepolens mediekapital er nyhedsdistribution, som bygger på en arbejdsekstensiv rationalitet og på et princip om (hurtig) spredning af let tilgængelige informationer. Fontænemediers kompetence er dagsordenkonfirmering. Empiriske undersøgelser viser, "at internetnyhederne er mere rå og mindre bearbejdede. Hurtighed er et vigtigere kriterium end grundighed, så webnyheder har sjoldent voret igennem lang journalistisk produktionstid, hvis der da ikke slet og ret er tale om versioneringer, lån og ran" (Willig \& Lund, 2009: 164). Det distribuerede nyhedsmediefelt er spændt ud mellem en "dagsordensætter" og en "spreder" i kulturel masseproduktion. 
Med de ovenfor skitserede nyhedsmediefelter foreslår jeg, at pressens nyhedsmediefelt mister styrke, da den tabloide pol svækkes, hvorved konkurrencen om kulturpræsentationen mellem det borgerligt-væsentlige og det folkeligt-fængende bliver mindre regulerende for nyhedsmediernes adfærd. Det kan være homologt til svækkelsen af klassekulturer i den moderne velfærdsstat. Pressens nyhedsmediefelt afløses af det distribuerede nyhedsmediefelt, hvor konkurrencen står mellem aktørmediers indflydelse gennem dagsordenfastsættelse og fontænemediers spredning og konfirmering af dagsordenen. Disse ændrede konkurrenceforhold ændrer de regulerende mekanismer i nyhedsmediernes kulturelle masseproduktion. Af figur 2 fremgår det, at det distribuerede nyhedsmediefelt er ved at klinge af, eftersom gratisaviser har mistet oplag, TV 2 er igen blevet betalingsmedie (fra 2012), og flere webnyhedsmedier har fået såkaldte betalingsmure, hvilket svækker styrken af de gratis nyhedsmedier som fontænepol. Det kan bane vejen for andre poler og logikker i konkurrencen mellem nyhedsmedier.

\section{Det klassiske journalistfelt (1970'erne-1990'erne)}

Danske journalisters beskæftigelsesstruktur er ændret afgørende i de seneste årtier, hvilket udgør grundlaget for konstruktionen af to journalistfelter. Beskæftigelsestal på samme måde som oplagstal udgør et statistisk grundlag for feltkonstruktioner. Det første journalistfelt dækker perioden 1970'erne til 1990'erne, hvor journalister var ansat i en kommerciel avisindustri. Som erhvervsgruppe udviklede danske journalister professionslignende træk med eget fagforbund, uddannelse og tydelige faglige normer som fx kildebeskyttelse, adskillelse af fakta fra mening og reklame, standarder for nyhedsværdi og en arbejdsetik om at tjene offentlighedens interesse frem for partiinteresser eller kommercielle interesser. Erhvervsgruppen opnåede en autonomi og autoritet, så den i tilstrækkelig udstrækning selv kunne styre praksis (jf. Hallin \& Mancini, 2004: 35-36).

Journalisternes professionelle projekt indebar tillige en specialisering, hvilket er grundlaget for de spændinger, som jeg begriber med det klassiske journalistfelt. Det konstrueres med 
en refererende pol og en vagthundepol. Strukturen i feltet er ikke specifik dansk, men er homolog til distinktioner i journalistiske professioner i andre lande, herunder USA (jf. fx Patterson, 1998: 28). Den refererende pol kan repræsenteres af politiske journalister placeret på Christiansborg i Folketingets Presseloge. Polen bygger på et rationale, der tager empiriske udsagn for pålydende. Det kræver egenskaber som præcision og akkuratesse, så udsagn refereres 'fair' og 'akkurat', hvorved der etableres en performativ sandhed, uden at sandfærdigheden bedømmes eller certificeres (Ettema \& Glasser, 2006/1985: 128-129; jf. Philo, 2007: 179; Tuchman, 1978: 95; van Dijk, 1988: 70, 87). Rationalet giver kilderne mandat til at handle og positionere sig. Kilders udsagn modstilles ud fra et konfliktkriterium i dansk journalistik (Meilby, 2006/1996), hvorved de transformeres til den form for empirisme, der betegnes 'objektivisme', og som betragtes som den klassiske, journalistiske stil i Danmark (Jørgensen, 2007: 11, 24). Den bygger på eksistensen af et faktisk domæne af basale, ufortolkede, hårde fakta, der tjener som fundament for empirisk viden (Ettema \& Glasser, 2006/1985: 130).

Den anden pol, vagthundepolen, bygger på et rationale om et kritisk og dybdegående undersøgende princip (van Eijk, 2005), som kan repræsenteres af gravergrupper placeret på større nyhedsredaktioner, men det findes også blandt lokaljournalister (jf. Ekström, Johannson \& Larsson, 2006). Det kræver kvalifikationer til at granske, skabe nye fakta, fortolkninger eller sammenhænge og til at levere en betydelig journalistisk anstrengelse. Kilders udsagn afprøves for at nå frem til "den bedst opnåelige version af sandheden" (Bjerg, 2005; Haagerup, 2008; Mylenberg \& Davidsen-Nielsen, 2008; jf Ekström, 2002: 270-272). Ansvarlige aktører udpeges og konfronteres med ofre og konsekvenser, og deres handlinger sanktioneres i et moralsk domæne (fx Hunter \& Hanson, 2011: 6-8, 12; jf. Ettema \& Glasser, 2006/1985: 138).

Spændingen i det klassiske journalistfelt er mellem poler indeholdt i den journalistiske profession, hvilket betyder, at kampene primært handler om den symbolske værdi af divergerende journalistiske kapitaler: objektivistisk mandattildeling og kritisk moralistisk sanktionering, dvs. om et interview med en højt placeret kilde er mere anerkendelsesværdigt end afsløringen af skjulte forhold. Det betyder tillige, at kampene i det klassiske 
journalistfelt kun sekundært handler om virkelighedens repræsentation. Helt anderledes forholder det sig i det næste journalistfelt.

\section{Det interventionistiske journalistfelt (2000'erne)}

Sidst i 1990'erne begyndte beskæftigelsesstrukturen for danske journalister at ændre sig. I 1990'erne var få journalister ansat i kommunikationsafdelinger. Efter år 2000 er et stigende antal journalister beskæftiget med intern og ekstern kommunikation, strategisk information og PR i virksomheder og private og offentlige organisationer uden for den traditionelle nyhedsindustri (jf. Willig og Lund, 2008: 166; Davidsen-Nielsen, 2010; Svith, 2011: 130-132). Det er stillinger tæt på eller i virksomheders ledelse som kommunikationschefer, informationsmedarbejdere, PRmedarbejdere, spindoktorer m.m.

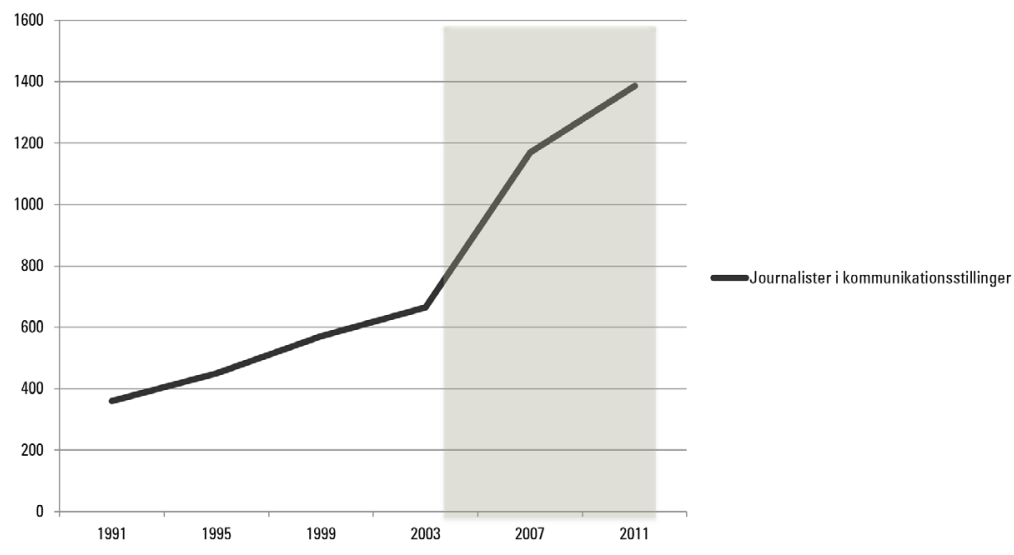

Figur 3. Journalister ansat i kommunikationsstillinger og det interventionistiske journalistfelt

Figur 3 viser et stigende antal journalister ansat i kommunikationsstillinger. I Danmark opstår der med disse strategiske informationsjournalister en gruppe, som orienterer sig mod gruppen af nyhedsjournalister og modsat. Det skaber en distinktion i den danske journaliststand, som er grundlaget for at konstruere det interventionistiske journalistfelt med en strategisk informati- 
onspol og en nyhedsjournalistisk pol. I 2009 positionerer danske nyhedsjournalister sig primært i en "kritisk-aktiv rolle", som en offentlighedens repræsentant, der er skeptisk og kritisk over for personer med politisk eller økonomisk magt, og som kritisk analyserer og fortolker komplekse emner (Skovsgaard m.fl., 2012: 161). Eller som en nyhedsjournalist formulerer sig, "man [er] oppe imod et helt departement af spindoktorer, journalister og topprofessionelle kommunikationskonsulenter [...] De toenker alle taktisk $i$, hvordan historien kan drejes, spinnes eller måske endda helt afvoerges. Derfor må man også selv toenke” (Albrecht, 2010).

I Danmark opstod gruppen af strategiske informationsjournalister sent i forhold til fx USA, hvor spændingen mellem informationsjournalister ansat som presseagenter i stat eller virksomheder og journalister ansat i nyhedsmedier allerede i 1920'erne ændrede nyhedsjournalisternes praksis (Schudson, 2013). Konkurrenceforhold tillægges stærke effekter. " The clearest force driving reporters towards a formal conception of their jurisdiction was in fact competition with hired publicity agents ... Reporters ... reaction led on the one hand to a renewed drive for formal professional structures, and on the other hand a frank recognition of subjectivity in reporting." (Abbott, 1988: 225). Dette journalistfelt bygger på andet og mere end det, der almindeligvis forstås ved den journalistiske profession.

Professioner er defineret ved en særlig arbejdsmoral, hvor personlige sym- eller antipatier ikke må indvirke på arbejdets udførelse (Staugård, 2011: 170-171). I den journalistiske profession antager denne arbejdsmoral karakter af en public service-etik om at være i offentlighedens tjeneste. Hvis journalister i stedet varetager økonomiske eller politiske interesser, betegner Hallin og Mancini det som instrumentalisering (Hallin \& Mancini, 2004: 37-38), eller med andre ord de-professionalisering. Det indebærer, at strategiske informationsjournalister, der varetager bestemte politiske, økonomiske eller organisatoriske interesser, falder uden for denne gængse definition på en journalistisk profession. Strategiske informationsjournalister kan udgøre en pol, som bevidst eller ubevidst reagerer på en nyhedsjournalistisk pol og omvendt. Når nyhedsjournalister antager, at de tjener offentligheden og varetager en almen interesse, står de i et objektivt 
modsætningsforhold til informationsjournalister, der antagelig tjener særinteresser.

Den nyhedsjournalistiske pols rationale er repræsentation af virkeligheden ud fra almene interesser, hvilket kræver iagttagelser af anden orden frem for første orden. ${ }^{8}$ Nyhedsjournalistens kilder fra den oppositionelle strategiske informationspol fremstår ikke som informanter, men som repræsentanter, hvis udsagn og adfærd kræver fortolkning og konstruktion af alternative virkelighedsrepræsentationer. Avisjournalister anvender ikke kilder tæt på den strategiske informationspol til at forklare virkelighedens fænomener i deres nyhedsartikler. I stedet kalder de på eksperter fra i politisk forstand neutrale institutioner som universiteter til at forklare, eller de forklarer selv, hvordan virkeligheden hænger sammen (Svith, 2011: 379-391). Den nyhedsjournalistiske kapital er kompetencer til symbolsk intervention i fx politik, økonomi og kultur.

Den strategiske informationspols rationale er at sikre legitimiteten i offentlige repræsentationer af virkeligheden ud fra særinteresser, eller med andre ord en intervention i nyhedsjournalistikken. Som det formuleres af kommunikationsdirektør i DSB og tidligere journalist på TV Avisen, Anna Vinding, i journalisternes fagblad: "Det er ret enkelt: En journalist skal varetage almenvoeldets interesser. Jeg skal varetage DSB's interesser" (Hesselager, 2009). Formålet med organisationers og virksomheders 'public relations' er påvirkning af journalister og befolkning med henblik på at påvirke politikerne (Hansen, 2004: 204). "Powerful players devote massive resources to advancing their interests precisely by imposing such patterns on mediated communications" (Entman, 2007: 164). Den strategiske informationsjournalistiske kapital er informations- og kommunikationskompetencer til symbolsk intervention i nyhedsjournalistik.

De to poler i det interventionistiske journalistfelt har dermed begge en kommunikativ kapacitet til at intervenere i begivenhedsstrømmen med henblik på at påvirke handlinger og skabe begivenheder ved at producere og transformere symbolske former (Thompson, 1995: 17). Eftersom "almost any nontrivial reality will be controversial-susceptible to two or more framings" (Entman, 2007: 166), står kampen i feltet om, hvilke opfattelser af virkeligheden der opnår legitimitet og dominans, hvorved jour- 
nalistisk kapital konverteres til symbolsk kapital eller magt. Det er en kamp, som må forventes at have større samfundsmæssig og social effekt end den professionsinterne konkurrence mellem undersøgende og refererende journalister i det klassiske journalistfelt. Hvilke konsekvenser afhænger af de konkrete styrkeforhold i feltet. En empirisk undersøgelse viser, at den strategiske informationsgruppe fx dominerer over den journalistiske nyhedsgruppe i et regionalt underfelt af det interventionistiske journalistiskfelt, således at sundhedsvæsen og sundhedspolitik i de regionale nyhedsmedier repræsenteres af den strategiske informationsgruppes symbolske konstruktioner (Buch \& Svith, 2013).

\section{Feltteorien som analytisk redskab}

I denne artikel har jeg peget på behovet for en betydeligt mere nuanceret tilgang til journalistik og medier end den, Bourdieu præsenterer (jf. Marliére, 1998). Formålet var at undersøge, hvordan Bourdieus feltteori kan bidrage til forståelsen af journalistik og nyhedsmedier på mesoniveau. At felt og profession er to forskellige måder at begribe nyhedsproduktion på, viser konstruktionen af det Interventionistiske journalistfelt (jf. Bourdieu \& Wacquant, 1992: 241-245). Jeg argumenter, at feltteorien er i stand til at identificere historisk og socialt afgrænsede strukturer i nyhedsmedier og journalistik, der med sandsynlighed disponerer nyhedsmediers og journalisters praksis.

For det første illustrerer feltskitserne, at forskellige konkurrencelogikker i nyhedsmedier og journalistik giver grundlag for at etablere nyhedsmedier og journalister som særskilte analyseobjekter, der dermed udgør forskellige variable i forklaringer af kulturel masseproduktion af nyheder.

For det andet understreger feltskitserne feltteoriens relationelle karakter, hvor praksis reguleres af aktører, der kæmper i opposition til hinanden i en afgrænset mikroverden. Det betyder, at et felts effekter må bestemmes gennem identifikation af effektskabende bipolære grupperinger. Feltskitserne ovenfor identificerer fire grupperinger af nyhedsmedier: publicistmedier, tabloidmedier, betalte nyhedsmedier, gratis nyhedsmedier 
og fire grupperinger af journalister: vagthundejournalister, refererende journalister, nyhedsjournalister og strategiske informationsjournalister. Med feltskitserne foreslår jeg, at disse grupper danner to bipolariteter med effekter på journalisters og mediers praksis via aktion og reaktion.

For det tredje illustrerer feltskitserne, at det giver mening ikke at reducere konkurrencen i kulturel masseproduktion som journalistik og nyhedsmedier til en konkurrence mellem indtjening (økonomisk kapital) og information (kulturel kapital). Feltanalyser skal således identificere den specifikke logik, der driver kampene i det pågældende felt for at kunne forstå, hvordan praksis reguleres. Jeg har i feltskitserne ovenfor foreslået fire konkurrencelogikker, hvis særtræk bestemmes af de kapitaler, som konkurrencen står mellem. De fire sæt kapitaler er 1) borgerligt-væsentligt versus folkeligt-fængende, 2) dagsordenfastsættelse versus dagsordenkonfirmering, 3) kritisk moralistisk sanktionering versus objektivistisk mandattildeling og 4) almeninteresseframing versus særinteresseframing. Disse fire konkurrencelogikker disponerer til forskellige former for kulturel masseproduktion.

Denne artikel peger på behovet for yderligere forskning i specifikke (under)felter af nyhedsmedier og journalistik med henblik på at forklare forandringer i nyhedsproduktion. En nuanceret anvendelse af feltteori på mesoniveau fremstår som et velegnet analytisk redskab i en sådan medie- og journalistikforskning.

\section{REFERENCER}

Abbott, Andrew (1988). The System of Professions, Chicago: University of Chicago Press.

Albrecht, Jakob (2010). "Hvad er din vinkel?", Journalisten, 16 (3), 10.2010 .

Albæk, Erik (2004). Eksperter kan væere gode nok, men ... : Om fagkundskabens politiske vilkår i dansk demokrati, Århus: Aarhus Universitetsforlag.

Anderson, Christopher (2008). "Journalism: Expertise, Authority and Power in Democratic Life", pp. 248-264, i David Hesmondhalgh and Jason Toynbee (edt.). The Media and Social Theory, London \& New York: Routledge.

Bennett, W. L. (1990)."Toward a theory of press-state relations", Journal 
of Communication, 40, 103-125.

Benson, Rodney \& Erik Neveu (eds) (2005). Bourdieu and the Journalistic Field, Cambridge: Polity.

Bird, Elisabeth S. (2009). "Tabloidization: What is it, and Does it really Matter", pp. 40-50, in Barbie Zelizer (eds), The Changing Faces of Journalism: Tabloidization, Technology and Truthiness, London: Routledge.

Bjerg, Lars (2005). Voer god. Om etik, voerdier og kvalitet i journalistik, Århus: Ajour.

Bourdieu, Pierre (1991/1984). "Social Space and the Genesis of 'Classes”, pp. 229-250, in Pierre Bourdieu, (1991). Language and Symbolic Power, Polity Press.

Bourdieu, Pierre (2005/1987). "Sociologens interesse”, Dansk Sociologi, Vol 16, No 4, pp. 91-98 ["L'intérêt du sociologue“, Economies et sociétés, XVIII, 10, octobre 1984/choses dites, Paris 1987].

Bourdieu, Pierre (2005/1988). “Om interesser og den symbolske magts relative autonomi: Svar på nogle indvendinger”, Dansk Sociologi Vol 16, No 4, pp. 101-116 [On Interest and the Relative Autonomy of Symbolic Power: A Rejoinder to Some Objections. Working papers and proceedings of the Center for Psychosocial Studies, no. 20 (Chicago 1988).]

Bourdieu, Pierre \& Loïc J. D. Wacquant (1992). An invitation to reflexive sociology, University of Chicago Press.

Bourdieu, Pierre (1996/1992). The Rules of Art: Genesis and Structure of the Literary Field, Cambridge: Polity Press.

Bourdieu, Pierre (1993). The field of cultural production, Polity Press.

Bourdieu, Pierre (1998/1994). Practical Reason: On the Theory of Action, Stanford: Stanford University Press.

Bourdieu, Pierre (2005/1995). “The Political Field, the Social Sciences Field, and the Journalistic Field”, pp. 29-48 in Rodney Benson \& Erik Neveu (eds), Bourdieu and the Journalistic Field, Cambridge: Polity.

Bourdieu, Pierre (1998/1996). On Television, New York: The New Press.

Bourdieu, Pierre (2004/2001). Science of Science and Reflexivity, Cambridge: Polity Press.

Bourdieu, Pierre (2008/2002). "Habitus - en praktisk sans”, Praktiske Grunde, 2, pp. 72-79.

Buch, Roger \& Flemming Svith (2013). "Hvordan trives ytringsfriheden i det regionale demokrati?", pp. 115-142 i Ejvind Hansen (red.). Ytringsfrihed til forhandling, Hans Reitzels Forlag. 
Cavling, Ole (1928). Journalistik. Kortfattet vejledning i moderne journalistik, Uournalism. A brief guide to modern journalism] København: Nordisk Forlag.

Christoforou, Asimina \& Michale Lainé (2014). "Re-Thinking Economics - why Pierre Bourdieu?”, pp. 3- 15, in Asimina Christoforou \& Michale Lainé (edt.). Re-Thinking Economics. Exploring the work of Pierre Bourdieu, New York: Routledge.

Couldry, Nick (2004). "Media meta-capital: Extending the range of Bourdieu's field theory”, pp. 165-192, in David L. Swartz \& Vera L. Zolberg (eds), After Bourdieu. Influence, Critique, Elaboration, Dordrecht: Kluwer Academic Publishers.

Couldry, Nick (2014). "Mediatization and the future of field theory”, pp. 227-245 in Knut Lundby (Ed.) Mediatization of communication, Berlin: Walter de Gruyter.

Davidsen-Nielsen, Hans (2010). "København har rekord i PR-ansatte", ["Copenhagen has a record in PR staff"] Politiken, 3.04.2010, p. 1.

DR (2007). Ny strategi for TV Avisen. Skarp og norvoerende, [New strategy for TV news. Sharp and present] DR, København.

Ekström, Mats (2002). "Epistemologies of TV journalism. A theoretical framework”, Journalism, 3 (3), pp. 259-282.

Ekström, Mats, Bengt Johannson, \& Larsåke Larsson (2006). Journalism and Local Politics. A study of scrutiny and accountability in Swedish journalism, Journalism Studies, Vol 7, No 2, pp. 292-311.

Entman, Robert M. (2007). "Framing bias: Media in the distribution of power”, Journal of Communication, 57(1), pp. 163-173.

Ettema, James \& Theodore Glasser (2006/1985). “On the Epistemology of Investigative Journalism”, pp. 126-139, in G. Stuart Adam \& Roy Peter Clark (eds), Journalism. The Democratic Craft, New York: Oxford. Fairclough, Norman (2008/2003). Analysing discourse. Textual analysis for social research, London: Routledge.

Franklin, Bob (2008). “The future of Newspapers”, Journalism Studies, 9 (5), pp. 630-641.

Gerring, John (2005). "Causation: A Unified Framework for the Social Sciences”, Journal of Theoretical Politics, vol. 17, nr. 2, pp. 163-198.

Giddens, Anthony (1984). The Constitution of Society, Cambridge: Polity Press.

Hallin, C. Daniel \& Paolo Mancini (2004). Comparing Media Systems. Three Models of Media and Politics, New York: Cambridge University Press. 
Hansen, Jens Otto Kjær (2004). I andres brød, Århus: Ajour.

Hesmondhalgh, David (2006). "Bourdieu, the media and cultural production”, Media, Culture \& Society, Vol. 28, No. 2, pp. 211-231.

Hesmondhalgh, David and Jason Toynbee (ed.)(2008). The Media and Social Theory, London \& New York: Routhledge.

Hesselager, Øjvind (2009). "Gå ikke over sporet, der kommer spin", Journalisten, 18.11.2009.

Hjarvard, Stig (1999). TV-nyheder i konkurrence, Frederiksberg: Samfundslitteratur.

Holm, Hans-Henrik, Flemming Svith \& Kate Kartveit (2008). "Konklusion: Public service-nyheder som god journalistik?", pp. 217-234, in Hans-Henrik Holm, Flemming Svith \& Kate Kartveit (red.), Når nyheder bliver til - på DR og TV 2, Århus: Ajour.

Hovden, Jan Fredrik ( 2012). "A Journalistic Cosmology. A Sketch of Some Social and Mental Structures of the Norwegian Journalistic Field", Nordicom Review 33 (2012) 2, pp. 57-76.

Hunter, Mark Lee, Nils Hanson, Rana Sabbagh, Luuk Sengers, Drew Sullivan, Flemming Tait Svith \& Pia Thordsen (2011). Story-Based Inquiry: A manual for investigative journalists, UNESCO: http://www.unesco. org/new/en/communication-and-information/resources/publications-and-communication-materials/publications/full-list/story-based-inquiry-a-manual-for-investigative-journalists/.

Haagerup, Ulrik (2008). Den bedst opnåelige version af sandheden, DR. Haagerup, Ulrik (2009). Mennesker og Medier, 30.01.2009, DR.

Iyengar, Shanto (1991). Is anyone responsible? How television frames political, Chicago: Univ. of Chicago Press.

Jensen, Klaus Bruhn (2008). Medier og samfund. En introduktion, Frederiksberg: Samfundslitteratur.

Jørgensen, John Chr. (2007). Journalistik med stil. Fra klassiske nyheder til fortcelling, Århus: Ajour.

Marliere, P. (1998). “The Rules of the Journalistic Field: Pierre Bourdieu's Contribution to the Sociology of Media”, European Journal of Communication, 13(2): 219-34.

McNair, Brian (1999). Journalism and Democracy: Evaluation of Political Public Sphere, London: Routledge.

Meilby, Mogens (2006/1996). Journalistikkens grundtrin, fra idé til artikel, Århus: Ajour.

Minke, Kim (2008). Aviskrigen. Dagblade i overlevelseskamp, København: Borgens Forlag. 
Morgenavisen Jyllands-Posten (2008). Journalistik, http://www1.jp.dk/ info/ journalistik.htm, downloaded 24.9.2008.

Mylenberg, Troels \& Mette Davidsen-Nielsen (2008). "Varm luft i en kold tid", Berlingske Tidende, 3.4.2008, kronik.

Myles, John F. (2010). Bourdieu, Language and the Media, Palgrave Macmillan.

Patterson, Thomas E. (1998). "Political roles of the journalist”, pp. 17-32, in Doris Appel Graber, Denis McQuail \& Pippa Norris (eds), The Politics of News: The News of Politics, Washington: CQ Press.

Peters, Chris \& Marcel Broersma (edt.) (2013). Rethinking Journalism. Trust and participation in a transformed news landscape, London: Routledge.

Philo, Greg (2007). "Can Discourse Analysis Successfully Explain the Content of Media and Journalistic Practice?", Journalism Studies, 8 (2), pp. 175-196.

Politiken (2006a). Genrekatalog, København: Politiken.

Politiken (2006b). "Sådan laver vi indblik - De fem nøgleord”, bilag, in Louise Zabel (2007). Politiken fra newspaper til viewspaper, Roskilde: RUC-speciale, downloaded 31.05.2007, http://www.ruc.dk/upload/ applica tion/pdf/f51d6748/Louise_Zabel.pdf.

Rosenbak, Steen (2006). "Kære læser", Morgenavisen Jyllands-Posten, p. 1, Erhverv \& økonomi, 02.10.2006.

Schrøder, Kim (2010). "Danskernes brug af nyhedsmedier: et nyt landkort. En pejling af danskernes navigation i nyhedsuniverset", Journalistica, 1, pp. 8-37.

Schudson, Michael (2013). “Would journalism please hold still!” pp. 191199, in Chris Peters \& Marcel Broersma (edt). Rethinking Journalism. Trust and participation in a transformed news landscape, London: Routledge.

Seidenfaden, Tøger (2006). "Velkommen: Årgang 123, Nummer 1" p. 2, Politiken, 01.10.2006.

Skovsgaard, Morten, Erik Albæk, Peter Bro \& Claes de Vreese (2012). "Media Professionals or Organizational Marionettes? Professional Values and Constraints of Danish Journalists", pp. 155-170, in David Weaver \& Lars Willnat (eds.). The Global Journalist in the 21st century, New York: Routledge.

Staugård, Hans Jørgen (2011). "Professionsbegrebet”, pp.161-175, i Martin Blok Johansen \& Søren Gytz Olesen (red.), Professionernes sociologi og vidensgrundlag, Aarhus: VIA Systime. 
Svith, Flemming (2011). Nyhedsjournalistik - bedre end sit rygte? Et sociologisk og diskursanalytisk studium afforklaringer $i$ danske aviser gennem 40 år, Århus: Politica.

Svith, Flemming (2014). "Grundlaget for journalisters viden", pp.119146, i Gitte Sommer Harrits, Martin Blok Johansen, Jens Erik Kristensen, Lars Thorup Larsen \& Søren Gytz Olesen (red.). Professioner under pres. Status, viden og styring, Aarhus: VIA Systime.

Søllinge, Jette D. (1999). "Historien om den politiske journalistik - Et drama i flere akter uden afslutning”, pp. 76-96, in Erik Meier Carlsen, Peter Kjær \& Ove K. Pedersen (red.), Magt og fortcelling, Århus: Ajour.

Thompson, John B. (1995). The Media and Modernity: A Social Theory of the Media, Stanford: Stanford University Press.

Tuchman, Gaye (1978). Making News. A Study in the Construction of Reality, New York: The free Press.

van Dijk, T.A. (1988). News as Discourse, New Jersey: Lawrence Erlbaum Associates.

van Eijk, Dick (ed.)(2005). Investigative Journalism in Europe, Amsterdam: Vereniging van.

Vestergaard, Per (2007). Midtjyske Medier, i Mennesker og Medier, [People and Media] 30.03.2007.

Walgrave, Stefaan \& Peter van Aelst (2006). ”The Contingency of Mass Media's Political Agenda Setting Power: Towards a Preliminary Theory", Journal of Communication, 56 (1), pp. 88-109.

Willig, Ida \& Anker Brink Lund (2009). ”Publicistisk produktion: Sådan gør man nå-heder til nyheder”, pp. 163-178, in Anker Brink Lund, Ida Willig \& Mark Blach-Ørsten (red.), Hvor kommer nyhederne fra? Den journalistiske fødekcede i Danmark før og nu, Århus: Ajour.

Zelizer, Barbie (2004). Taking Journalism Seriously, Thousand Oaks: Sage.

\section{NOTER}

1 I en tidligere version har feltskitserne været anvendt som variation på den uafhængige variabel i et undersøgelsesdesign af journalistisk praksis (Svith, 2011).

2 Jeg fokuserer i denne artikel på feltinterne dynamikker frem for felters gensidige påvirkning af hinanden.

3 Habitus er af permanente måder at være på, måder at 'registrere', handle og tænke på eller en mental struktur, der består af et system 
af varige (snarere end permanente) mønstre, skemata eller strukturer for perception, tænkning og handling (Bourdieu, 2008/2002: 73).

4 De otte aviser har siden 1930'erne haft mindst 75 procent og typisk 90 procent af det samlede avismarked for landsdækkende betalingsaviser i Danmark. Beregnet ud fra hverdags- og søndagsoplag på tal for 2. halvår fra Dansk oplagskontrol (http://www.do.dk/).

5 Beregningerne er foretaget på baggrund af data fra Dansk Oplagskontrol. Den Blå Avis er ikke medtaget i opgørelsen over landsdækkende gratisaviser.

6 Det gælder fx Politiken ((Politiken, 2006a; 2006b); chefredaktør Tøger Seidenfaden, Politiken, 1.10.2006), Morgenavisen Jyllands-Posten (erhvervsredaktør Steen Rosenbak, Morgenavisen Jyllands-Posten, 2.10.2006), Midtjyske Medier (ansvarshavende chefredaktør Per Vestergaard, i Mennesker og Medier, 30.03.2007) og DR ((DR, 2007: 38); nyhedschef Ulrik Haagerup, Mennesker og Medier, 30.01.2009).

7 Medlemmer af Dansk journalistforbund, der er ansat i kommunikationsstillinger i offentlige og private organisationer. Dansk Journalistforbund (2014). Udviklingen i beskæftigelsen for DJ-medlemmer, http:// journalistforbundet.dk/Filer/DJ/Dokumenter/Job\%20 og\%20loen/ Loenstatistik/L\%C3\%B8nnotater\%20m.m.\%20for\%202013/07.\%20 Udviklingen $\% 20 \mathrm{i} \% 20$ beskaeftigels en $\% 20$ for $\% 20 \mathrm{DJ}$-medlemmer. pdf\#page=1\&zoom=auto,-76,848

8 Jeg foreslår her en epistemologisk parallel (se også Jensen, 2008: 45) til Giddens' beskrivelse af den dobbelte hermeneutik i samfundsvidenskab (Giddens, 1984: 284). 